\title{
Legal Measures for Gratitude for Elderly Providing Social Security to the Elderly
}

\author{
Pornpen Traiphong ${ }^{1}$, Thanachart Paliyawate ${ }^{2}$, Yutthapong Leelakitpaisarn ${ }^{3}$ \\ ${ }^{1,3}$ School of Law and Politics, Suan Dusit University, ${ }^{2}$ Faculty of Law, Ramkhamhaeng University

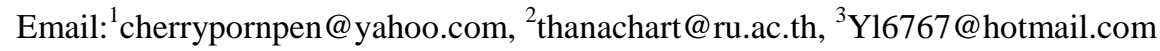

\begin{abstract}
This research aims to analyze policies, laws and strategies of foreign countries providing social security to the elderly especially those related to law on gratitude. The research utilized a mixed methods research including both qualitative research and quantitative research. The qualitative research exercised in-depth interview to 30 experts and related persons, document research and group discussion among 10 people. The quantitative research was utilized by questionnaires towards sample groups in 4 regions, totaling 400 people and using quota sampling method to collect data which were analyzed using descriptive statistics and reference research. The significant results of this research were summarized as follows: conversion of filial piety to be the law on gratitude may be done as same as 4 foreign countries where provide development of the law on gratitude. However, it must be high time of extreme necessity and appropriateness if such law on gratitude has coercion manner, penalty and other punitive measure in general against violators, otherwise detrimental effect will be occurred to the elderly, family and society. Body of knowledge of this article will enhancing the quality of life for the elderly.
\end{abstract}

Keywords

Legal Measures, Elderly, Social Security

Article Received: 10 August 2020, Revised: 25 October 2020, Accepted: 18 November 2020

\section{Introduction}

The number of older/elderly people in Thailand is persistently increasing at a higher rate. The United Nations defines population aged 65 and above by over $7 \%$ of the total population as an aging society, by over $14 \%$ as an aged society, and by over $20 \%$ as a super aged society. Result of the 2017 survey of the older population in Thailand indicated that Thailand is stepping into an aged society with approximately 11.3 million people aged 60 years and above or $16.7 \%$ of whole Thai population [1]. The statistics also indicated their number tend to be rapidly and persistently rising in each year. Their economic, social, health and mental dependence ratio would be likewise ascending. Meanwhile, proportion of child and labor-age population have steadily declined. When considering ASEAN member countries, the number of older people of Thailand and Singapore were in the top rankings and expected that these two countries would have proportion of older people by over $30 \%$ in 2040 [2].

Several national economic and social development plans mention several aspects of Thai society affecting the older population such as inequality, economic concentration and development. Policy and legal considerations relating to them involve subsistence allowance and social welfare in light of income and social security for the elderly[3]. In this regard, Thai elderly are fortunately entitled to any of Civil Servant Medical Benefit Scheme (CSMBS), Social Security Scheme (SSS), Universal Coverage Scheme (UCS) and monthly subsistence allowance in progressive rate for the elderly as a result of government policy and by law. But the huge budget and resources have been allocated and spent more and more in those social welfare or security schemes and may be restrictively supplied in the long run. More difficulties of law and policy relating to social welfare and security may come up in the future among the elderly's limited access to labor market, social changes, less birth and negative attitudes towards the elderly, etc.

It is interesting to explore how current role and responsibilities of each family provided to elder parents and other aged people, as Japan's policy towards the older population states that the public sector should promote selffamily care of the elderly rather than emphasis on providing social welfare. Thus, elder care should be transferred to their own family; meanwhile, public sector may provide support and assistance as deemed appropriate or on case-bycase basis.

In addition to basic rights of the elderly are recognized by international law, principle and provisions of gratitude (Filial Piety) provided in laws of many countries i.e. The People's Republic of China ("China"), the Republic of Singapore ("Singapore), the Republic of India ("India") and the French Republic ("France") which based on intensive attention to solve irreverence, non-deference, ingratitude, non-requitement and others presently encountered by the elderly. Such domestic laws exist with a view to protecting the elderly both physically and mentally from neglect by their own children and poor caring and support of the elderly or abandoning their parents.

As to none of specific statutes of Thai law on gratitude provided, the researchers view a development of law on gratitude (Filial Piety Law) may be an optional tool to promote self-family care of the aged parents rather than merely providing social welfare and security to the elderly. Such tool can be inclusive in line with relevant plan, strategy and law so as to prepare for greater number of the older population in the future and conform with a Thai value adhered to be descendants' duty from the old days in providing parental care which is gratitude and auspicious to their own life.

Few research questions are (1) whether policy and development of mandatory law for entitlement of a right to 
claim for maintenance and expenses and/or penalty against any defaulting descendants for restoring filial piety are appropriate or not and (2) is it high time to provide this nature of policy and law in Thailand for social security among changing current Thai context?

\section{Research Objectives}

This research aims to analyze policies and laws of foreign countries that provide social security for the elderly, especially those relating to the Filial Piety Law.

\section{Research Methods}

\section{Research Design}

The research utilized a mixed method including both qualitative research and quantitative research. The qualitative research exercised in-depth interview to 30 experts and related persons by randomized research Purposive sampling is used according to the eligibility criteria of different types of experts, document research and focus group discussion among 10 people by inviting representatives from various aspects. The quantitative research utilized questionnaires towards sample groups in 4 regions i.e. North, Northeast, Central and South, totaling 400 people and using quota sampling method to collect data which were analyzed by descriptive statistics and reference research.

\section{Research Process}

To study and analyze in the following scope and methodology:

1) Opinions on problems and obstacles linked to legal measures under the filial piety law of foreign countries and legal measures under Thai laws and regulations; opinion on policies and strategies on social security for the elderly, especially relating to the filial piety law, by qualitative approach including in-depth interviews to experts and related people;

2) Laws, policies and strategies of foreign countries that provide social security for the elderly, especially relating to the filial piety law, by qualitative approach including documentary research;

3) Legal measures relating to the elderly of Thailand and foreign countries, by qualitative approach including group discussions among experts and related people and

4) Opportunities of enhancing social security for the elderly, especially in connection with the filial piety law for promoting effective elder care, by qualitative approach including group discussions among experts and related people

\section{Results}

\section{Results from document research}

A comparative study of structure of population among 4 countries where have specific filial piety law or law being scope of filial piety law. According to the United Nations' report [4], World Population Ageing 2015, India has not yet been classified as ageing society. China, Singapore and Thailand were classified as ageing society since these countries' population aged 65 and above were by over $7 \%$. France population aged 65 and above was by over $14 \%$ classified as aged society. In addition, Japan was a superaged society by over $25 \%$ of the population aged 65 years and above since 2013, in other words, a quarter of Japanese population are the elderly and forecasted to continue growing.

With reference to concept, definition and theory of law and social science, especially elderly, filial piety value, deinstitution approach, nature of law in relation to legal development pursuant to social change, they can be connected to policy and legal measures on gratitude/filial piety. The "filial piety" -- consists of gratitude and requitement. Its value reflects, also referring to Chinese philosophy, both inner feelings and acts of love, care, appreciation, respect or reverence, support and requitement towards parents and other benefactors regardless of being aged people. Owing to scope of this research, the filial piety focuses on the elderly who have benefaction to other people. The filial piety value is included in the state policy and plan on the elderly which are integral part of indicating governmental attention and direction of operating works for the elderly i.e. protection of rights, provision of care and welfare, development of the quality of life etc. Besides, application of law is integral part of mechanism and a tool of implementation either legislating new law or amending existing law.

\section{Policies}

In respect of policy of China, Singapore, India and France, related and interesting policy on the elderly as follows:

China: Promoting family care of the elderly and former system of supporting family care by training family members to provide care of elder parents and other elder members of the family as well as promoting knowledge, skill and capacity to their children and family members by emphasis on mental health of the elderly impacted by changing social change in China.

During preceding decade, Chinese government formulated significant policy and purpose of operating elder care i.e. caretaker and non-abandonment, medical treatment of ill people, obtaining education as desired, employment as desired, having happy life and self-esteem. The 2010 survey found the elderly being ill in moderate and serious level receive their own family's care which is informal and likely to be the most important. Only less part of all elderly relied on or receive professional care [5]. More important factors were on their descendants and family members in providing care, time and chance of meeting with the elderly even though communication advanced technology of communication is prevalent.

Singapore: The Government of Singapore formulated a motto "Successful Ageing for Singapore" with various policies and action plans based on centralization of management and "de-institution approach" by adherence of the following 3 principles i.e. self-reliance and social responsibility, family-reliance and multiple sectoral cooperation. Its focuses include family's duty to bring up 
elder parents, maintaining value of family institution and multi-dimension cooperation approach, not solely on state duty to provide social welfare for the elderly and on receiving by the elderly.

France: As huge amount of money has been spent for various social welfares particularly the dependent elderly, the French government was also more enthusiastic to provide elder care and could not accept irresponsible descendants and abandoned parents. Several policies and measures were provided in order to augment proper physical and mental care of the elderly in urban area, and at home especially the elderly being ill and without self-help and self-reliance and to monitor their well-being and movement aside from basic necessities and maintenance.

India: Policy emphasizing on value of family institution in providing physical, mental and emotional care for the elderly, on supporting cohabitation among different generations in the family by tax reduction and on duty to act in pursuance with the filial piety. Relevant mechanism has been set up to enhance knowledge, skill and capacity to provide elder care both in urban and rural areas especially most low-income population and various categories of the elderly in needs of subsistence, safety and security

\section{Laws}

Owing to changing of social context and value of filial piety in the aforesaid countries especially during preceding decade, it is optimistic that their public sector has turned to pay more attention on situations and problems of the elderly. As a result, the aforementioned policy, plan and legal measures (both specific filial piety law and law being scope of filial piety law) in multi-sectoral and multi-level for various categories of the elderly are broadly provided in order to provide better elder care, protection of rights, protection of their rights and enhancing their quality of life. Nature of law-making and intent of laws including both specific filial piety law and law being scope of filial piety law of 4 foreign countries were as follows:

\begin{tabular}{|c|c|c|}
\hline $\begin{array}{l}\text { Country and law } \\
\text { title }\end{array}$ & $\begin{array}{l}\text { Nature } \\
\text { of law- } \\
\text { making }\end{array}$ & Intents of law \\
\hline $\begin{array}{l}\text { France } \\
\text { Civil Code, } \\
\text { amendment being } \\
\text { in force in } 2004\end{array}$ & $\begin{array}{l}\text { Existing } \\
\text { code } \\
\text { amended }\end{array}$ & $\begin{array}{l}\text { - Child and others } \\
\text { being subject to the law } \\
\text { provide more caring for the } \\
\text { elder parents' mental and } \\
\text { financial needs and not } \\
\text { abandon them. }\end{array}$ \\
\hline $\begin{array}{l}\text { China } \\
\text { Law on Protection } \\
\text { of the Rights and } \\
\text { Interests of the } \\
\text { Elderly, } \\
\text { amendment being } \\
\text { in force in } 2015\end{array}$ & $\begin{array}{c}\text { Existing } \\
\text { specific } \\
\text { law } \\
\text { amended }\end{array}$ & $\begin{array}{l}\text { - Recognize more } \\
\text { rights and interests for the } \\
\text { elderly } \\
\text { - Child and others } \\
\text { being subject to the law } \\
\text { provide more caring for the } \\
\text { elder parents' mental and } \\
\text { financial needs }\end{array}$ \\
\hline $\begin{array}{l}\text { Singapore } \\
\text { The Maintenance } \\
\text { of Parents Act } \\
\text { (Cap 1678), } \\
\text { amendment being } \\
\text { in force in 2015 }\end{array}$ & $\begin{array}{c}\text { Existing } \\
\text { specific } \\
\text { law } \\
\text { amended }\end{array}$ & $\begin{array}{l}\text { - Child and others } \\
\text { being subject to the law } \\
\text { provide more caring for the } \\
\text { elder parents' mental and } \\
\text { financial needs } \\
\text { - Proving non-court } \\
\text { Tribunal to consider and }\end{array}$ \\
\hline
\end{tabular}

\begin{tabular}{|c|c|c|}
\hline & & $\begin{array}{l}\text { issue orders regarding } \\
\text { payment of alimony }\end{array}$ \\
\hline $\begin{array}{l}\text { India } \\
\text { Maintenance and } \\
\text { Welfare of } \\
\text { Parents and } \\
\text { Senior Citizens } \\
\text { Act, } 2007\end{array}$ & $\begin{array}{c}\text { New } \\
\text { specific } \\
\text { law } \\
\text { enacted }\end{array}$ & $\begin{array}{l}\text { - Aim at protecting } \\
\text { the elderly's life, property } \\
\text { and security } \\
\text { - Child and others } \\
\text { being subject to the law } \\
\text { provide more caring for the } \\
\text { elder parents mental and } \\
\text { financial needs } \\
\text { - Proving non-court } \\
\text { Tribunal to consider and } \\
\text { issue orders regarding } \\
\text { payment of alimony }\end{array}$ \\
\hline
\end{tabular}

Table 1. Nature of law-making and intent of specific filial piety law and law being scope of filial piety of 4 countries

The researchers sorted such laws of four countries into two categories:

1) First, stipulating broad range of conducts and prohibitions which emphasize protection of rights, protection of parents and elderly's life and property, reverence, caring especially mental needs, nurture covering essentiality for living such as 4 basic necessities, finance, medical care, health care, etc., as provided in the laws of France and China;

2) Second, emphasizing on bringing up, financial responsibility to the elderly by providing alimony, 4 basic necessities, medical examination and treatment, as provided in the laws of Singapore and India. which appears in the laws of Singapore and India

Aside from intents of those laws of 4 countries appeared in Table 1 above, intents of law can be summarized as follows: Aiming to protect the elderly's rights and interests directly, followed by protecting family institutions;

Aiming to raise public awareness, encourage and restore ethics, morality and filial piety in society, as found in positive way that all 4 countries destined to restore caring for elder parents or maintain relationship between parents and children as well as noted that whenever good conducts with filial piety towards the elderly, they would be equivalent to public sector devote money and resources to provide high-quality service or welfare for the elderly;

Aiming to arouse mindfulness or restore state of mind (personal and family) and to bring about behavioral adjustment of child and others being subject to the law rather than adequate punishment against wrongdoer or lawbreaker by applying nature of the law as a tool to control behaviors both doing and refrain from doing as required by the law.

The researchers also keep in mind that some countries enact and enforce effectively the law but some countries encounter the public's opposition due to its irrelevant consequences from the law enforcement.

The analytical study found that Chinese law being scope of filial piety law which is amended specific law is prominent and explicit in respect of protection of the elderly's rights and interests. Such law stipulates conducts and prohibitions for those are subject to the law to maintain family institution, promote Chinese pleasant values having so far been since ancient times, emphasize on role, duties, participation and conducts of various people related to the elderly with details of multi-facets of the elderly life. 
Indeed, this law does not provide explicitly penalty but authorizes the Court to exert discretion to consider and adjudge in this nature of civil case with appropriate penalty measure as deemed appropriate for instance the Court order the convict to visit his/her mother at least once a month and in public holidays.

After those laws of 4 countries were enforced, there were criticisms in every country. The law requires offspring to return hometown to visit and take care of elder parents perceived as a good intention and strategy to fulfill the elderly's mental loneliness and happiness. On the other hand, such legal measures may cause suffering and hardship to the descendants anyway and may cause more mental alienation or disaffection between generations. Actually, it is a matter of personal morality, mindfulness, ethics, emotion and feelings of the child or other descendants on their own. It is unnecessary for the authorities to formulate or oblige persons by law (Singapore's the Maintenance of Parents Act) to conduct like filial piety especially low-income child, child who fails to or has less capacity or other limitations to bring up his/her child and elder parents in the same time or to nurture improperly elder parents. Such legal requirements, indeed, cannot ensure whether or how good the elderly's needs has been satisfied or not.

Moreover, findings include issues of family relationships, inexplicit or ambiguity of the law, extensive and effective mechanism of law enforcement, the child's limitation to grant necessities to the elderly pursuant to changed society and family nature. Nevertheless, Chinese Law on Protection of the Rights and Interests of the Elderly may be a relevant model for revision of the law on elderly, various action plans and development of Thai law being scope of filial piety law.

\section{Research findings from in-depth interviews}

The results of the in-depth interviews related to policies and laws can be summarized as follows:

The primary needs of the elderly are income, medical treatment, care, love and warmth.

Family members are suitable to be frontline providing elder care. In this regard, culture of realization and good attitudes should be implanted. Any of government agency, institution, organization, elderly development center should be established to be focal point of personnel providing assistance, advice and various knowledge together with virtuous cooperation among the elderly's descendants. Such personnel must be local or community people where the elderly reside therein. Besides, for long-term operations, their management must be systemized.

3) To develop legal measures of effective promotion or enhancement of filial piety to be social security, motivation and reinforcement would be more beneficial than making law that stipulates proper conducts and penalties. Such motivation may be created for proper operations in each organization and for encouraging family members to nurture and take care of the elderly well. Public sector must arrange support, campaign, mindfulness-raising and good family relationship that will bring about elder care in pleasant manner, culture of filial piety among offspring and family members, responsibility of elder care. better nurturing treatment for the elderly are as follows: (1) Right to take leave with pay for taking care of the elderly getting general ailments and severe illness, but if term of leave is longer than 1 month, such leave will be without pay; (2) Arrange vehicles and facilities to provide services of transporting or escorting the elderly in need of emergency medical care and treatment; (3) Tax reduction for those who patronize and nurture the elderly; (4) Set up the elder care center in day time for participating activities and caregiving; (5) Arrange proper medical facility and nursing home for the elderly and (6) Provide discount in physical checkup and medical care in special occasion. Most of all, public sector should support budget or subsidize expenses of elder care. As for legislation of the filial piety law for the elderly, local and community people had better take important role in implementation and participation of making the legal provisions due to their proximate relationship with the elderly. However, current situation has not yet reached a critical level to necessitate making the filial piety law. Applicable laws can be used in beneficial way by creating motivation and encouragement for better conducts of elder care, otherwise such law-making will become hindrance.

Obstacles or problems of developing policies and laws on elder care and support to be social security for the elderly are continuity of policy, lack of earnest operation and information being in accessible to local and community areas where the elderly resides. Accordingly, efficient enforcement should be done.

Auxiliary in development of policies and laws on elder care and provision of good and sustainable social security for the elderly are self-reliance value and intention of various related sectors i.e public entities, private entities, community, clubs, centers, individuals to jointly promote accurate value and knowledge about older people in order to satisfy the elderly's needs, not merely request for government assistance. In addition, such sections must stimulate people to have good attitudes towards the elderly and address the elderly's values. Most of all, family institution is highlighted in provision of elder care.

\section{Research findings from group discussions}

Most participants do not agree to making a new law or development of a law being scope of the filial piety. As for development of the filial piety law of Thailand, insertion of some provisions into relevant applicable laws and regulations can be more possible than legislating new law or the Act. Otherwise, it will become an ingratitude. Most participants agree to development of law on enhancement, motivation of the filial piety value and practices, as local and community people have intensively endeavored to enhance trainings on family care which are very useful to the elderly.

\section{Results of quantitative data analysis}

The quantitative research methods were analyzed as general information of the respondents. Most respondents were female for 216 people, by 54.00 percent, and males for 184 people, by 46.00 percent, respectively. Most of them were between 36-45 years old for 145 people, by 36.25 percent. Followed by the age between 23-25 years old for 117 
people, by 29.25 percent, below 25 years old for 73 people, by 18.25 percent, the age between $46-55$ years for 58 people, by 14.50 percent and over 56 years old for 7 people, by 1.75 percent, respectively.

As for the income of the respondents, most respondents have income between $15,000-25,000$ baht for 188 people, by 47.00 percent, having income less than $15,000 \mathrm{baht}$, for 80 people, by 20.00 percent, having income between 25,00135,000 baht for 72 people, by 18.00 percent, having income between $35,001-45,000$ baht for 53 people, by 13.25 percent, having income between 45,001-55,000 baht for 5 people, by 1.25 percent and income between 55,001-80,000 baht for 2 people, by 0.50 percent, respectively.

Most respondents did not live with the elderly, for 216 people, by 54.00 percent, and living with the elderly for 146 people, by 36.5 percent, respectively. The vast majority of the elderly in their families accounted for 363 people, by 90.75 percent and no elderly in the family for 30 people, by 7.50 percent, respectively. Most of them participated in caring for the elderly in the family for 181 visits, by 45.25 percent, taken them to the hospital for 72 people, by 18.00 percent, depletion of expenses for 56 people, by 14.00 percent and taking them for trips for 55 people, by 13.75 percent, respectively.

Opinions and suggestions on public sector's improvement of services for the elderly in the first priority vastly relate to state policies and actions on social welfare and social security for the elderly. Nevertheless, some of them suggest arousing descendants' mindfulness to nurture and care for the elderly and enhancing knowledge of the elderly care to descendants and family members. Opinions and suggestions on public sector's improvement of services for the elderly in the $2^{\text {nd }}$ ranking include trainings on elder care and keeping in mind of responsibility for the elderly in family to prevent solitary stay. Besides, other suggestions relating to the filial piety include enhancing value of filial piety towards the elderly in particular into new generations' acknowledgment and realization in concern of changing social context, etc. However, there were not implicit opinions and suggestions relating to development of the filial piety law in Thailand.

\section{Discussions}

In formulating policies, laws and operations in various facets relating to the elderly for social security, changing social context must be considered. From analysis of the policy on the elderly of the 4 countries together with the consideration of these countries' development level among changing social context, government policies have more emphasized caring for the elderly in various ways. In family, community, institutional and national level, their public sectors have more emphasized on promoting family care and family care support systems based on traditional life of the elderly and values added by enhancement of education, skills and abilities to descendants and family members. China and France focus on the elderly 's mental health affected by changing social context via contacts, visits and monitor of movement and well-being [6], in addition to providing 4 basic necessities, alimony and various expenses. Every country seeks to uphold values of the family institution, family relationships, family dependence usually being in charge of caring for the elder parents, elderly care and filial piety. Among such 4 countries, legislation and amendments have been made in accordance with these policy lines as well. When a violation or non-compliance is done, actions include exercise of claims litigation by parents or elderly. The laws require payment of alimony and its interest or taking compulsory measures to observe the Court's decisions or orders such as obliged to visit the elder parents for specified number of visits and period of time as well as punishments both fines and imprisonment, subject to circumstances [7].

Nevertheless, after the enforcement of the 4 countries' specific filial piety law and law being scope of filial piety law, many interesting criticisms pointed out both advantages and disadvantages of such law development. Some advantages are reflected from requirement to visit, nurture, take care of the elder parents perceived as fulfilment of the elderly's mental loneliness and happiness by gratitude, reverence, support and requitement towards them (other elder benefactors also included, if any). This complies with a result from in-depth interview, the participants pointed out primary needs of the elderly including care, love and warmth. In this way, it has been perceived as good intention and strategy to solve irreverence, non-deference, ingratitude, non-requitement and others; meanwhile, to restore and enhance the value of filial piety in the society among different generations that leads to indirect social security.

In the meantime, some disadvantages came from mandatory or coercion nature of law, penalty imposed and other punitive measure against violators. Such legal measures may cause suffering and hardship especially low-income child, child who fails to or has less capacity or other limitations to bring up his/her child and elder parents in the same time or to nurture improperly elder parents. Moreover, it has also caused more mental alienation or disaffection between generations. Strong points of view indicate matters of personal morality, mindfulness, ethics, emotion and feelings of the child or other descendants on their own. Hence, it is unnecessary for the authorities to formulate or oblige persons by law to conduct like filial piety. Such legal requirements, indeed, cannot ensure whether or how good the elderly's needs has been satisfied or not. These disadvantages and remarks are in compliance with opinions from group discussion among Thai participants that most of them viewed legislating new law can become an ingratitude and in pursuance with opinions from in-depth interview reflecting that current situation of Thailand has not yet reached a critical level to necessitate making the filial piety law which will become hindrance. Applicable laws can be used in beneficial way by creating motivation and encouragement for better conducts of elder care. Indeed, obstacles or problems of developing policies and laws on elder care and support to be social security for the elderly are continuity of policy, lack of earnest operation and information being inaccessible to local and community areas where the elderly resides.

\section{Recommendations}

\section{Recommendations for Practices}

1) Developing policies on social security for the elderly based on continuity of policy, earnest operations and 
information being accessible to local and community areas where the elderly resides;

2) Amendment or insertion of some provisions into relevant applicable laws and regulations;

3) Development of policies and laws in respect of motivation and reinforcement of the filial piety value and practices

\section{Recommendations for Further Research}

Should study opinions and needs of the people in the development of policy and law on the elderly regarding motivation and health insurance to support social security of the elderly.

\section{Conclusion}

Development of policy and mandatory law for entitlement of a right to claim for maintenance and expenses and/or penalty against any defaulting descendants for restoring and enhancing filial piety may be appropriate in some countries, although the public's opposition or irrelevant consequences found in some countries. For Thailand, under current social context relating to the filial piety which is neither critical, it has not yet been necessary for making the filial piety law. Development of policies on motivation and reinforcement to strengthen family institution or amendment of some provisions into relevant applicable laws and regulations can be possible to enhance social security for the elderly.

\section{Acknowledgement}

This research was supported by Suan Dusit University's research budget (State budget) for the fiscal year 2017

\section{References}

[1] National Statistical Office, Number of The Elderly from Survey of The Older Persons in Thailand by Sex, Region, Province and Area: 2017, 2018, from http://statbbi.nso.go.th/staticreport/page/se ctor/en/01.aspx

[2] S. Aruntip-paitoon, A policy proposal to prepare for aged society of Thailand, Bangkok: Office of Welfare Promotion, Protection and Empowerment of Vulnerable Groups, Ministry of Social Development and Human Security, 2014. (In Thai)

[3] Office of the Secretariat of the National Reform Steering Assembly, the National Social Reform Steering Committee, Preparedness of the elderly in significant and urgent reform agendas in 2017, Bangkok: Steering Committee Bureau 3,
Secretariat of the House of Representatives, 2017. (In Thai)

[4] United Nations, Department of Economic and Social Affairs, Population Division, World Population Ageing 2015, ST/ESA/SER.A/390, New York: United Nations, 2015.

[5] UNESCAP, Social Development Division, Long-term care for older persons in China. SDD-SPS Project Working Paper Series, Long-term Care for Older Persons in Asia and the Pacific, 2014.

[6] Martinez-Carter, K., How the elderly are treated around the world, The Week, (2013, July 23), Retrieved from http://theweek.com/articles/462230/howelderly-are-treated-around-world

[7] Celia Hatton, C., New China Law says children must visit parent, BBC News, (2013, July 1), Retrieved from http://www.bbc.com/news/world-asiachina-23124345 